\title{
Refusal to have children vaccinated: A challenge to face
}

\author{
Pablo R. Justich, M.D. ${ }^{a}$
}

\begin{abstract}
Vaccinations are a critical public health tool. However, a significant number of people decide not to get vaccinated or refuse to have their children immunized.

Physicians who recommend people who have an indication for vaccination not to get vaccinated go against official immunization programs, contradict sound scientific evidence, and put themselves at medical/legal risks because of their prescriptions. Parents who decide not to have their children vaccinated make this decision based on ideological or religious beliefs, or because of fads or snobbism, among other reasons, and this behavior affects their children's epidemiological protection and makes them prone to getting the disease.

Health effects of this kind are harmful for both those children and the community. Education and the adequate dissemination among the population, epidemiological and adverse event surveillance, a clear legal frame stating responsibilities, rights and obligations, and an informed consent for non vaccination, among other things, are tools that may help to eradicate such behavior. The best way to prevent vaccinerelated adverse events is to eradicate disease so that vaccination is no longer necessary.

Key words: vaccination, disease, prevention and control, vaccine coverage, herd immunity.
\end{abstract}

http:/ / dx.doi.org/10.5546/aap.2015.eng.443

\section{INTRODUCTION}

Towards the end of the 19 th century and early in the 20 th century, entire populations were decimated by polio, smallpox and measles epidemics, among others. Few would have imagined that only

a. Hospital La Vega. Murcia (Spain).

E-mail Address:

Pablo R. Justich, M.D.: pablojustich@gmail. com.

Funding:

None.

Conflict of interest: None.

Received: 4-9-2015 Accepted:4-13-2015 a few decades later, their eradication would be envisioned. Improvements in quality of life and essentially the introduction of immunizations as a health tool in a setting of joint and coordinated actions by health systems beyond the borders of any nation have led to a real revolution in health care.

Smallpox has been eradicated in the whole world, as polio in vast regions. In relation to measles, the World Health Organization (WHO) estimated that vaccines prevented
15.3 million deaths between 2000 and 2013. ${ }^{1}$ In this context and with available tools, the eradication of these and other diseases seems to be an attainable goal.

However, as the plan "health care for all in 2000" once seemed within grasp and the reality today is far from what it had been proposed, the possibility of putting an end to this scourge posed by vaccine-preventable diseases has also been threatened by the emergence of trends of thought that place certain individual prerogatives in conflict with overall wellbeing.

Luckily, most people understand that complying with official immunization guidelines is the right path towards improving children's health; but as reflected by the recent measles epidemic outbreaks, certain aspects should be corrected in order to achieve the proposed objectives.

The risk-benefit ratio of polio vaccine and measles, rubella and mumps vaccine admits no discussion from a medical and an epidemiological standpoint. However, part of the population considers susceptibility as a favorable alternative and shares these thoughts under highly arguable premises. Seeing that this position has been embraced not only by populations without access to enough information, but also by highly educated social groups, we should face this challenge trying to understand reasons that lead to making this decision in order to propose a more effective strategy.

\section{EPIDEMIOLOGY}

Significance. To understand the significance of approaching the problem posed by the refusal to have children vaccinated, let us first define some basic concepts. Polio was the 
main cause of childhood flaccid paralysis until the generalized use of the vaccine. Although polio cannot be cured, vaccines have proven effectiveness for prevention. ${ }^{2}$ Measles continues being one of the leading causes of preventable death in infants and toddlers, although there is a vaccine with proven effectiveness. Apart from the characteristics typical of each disease, it is known that in order to stop the circulation of a wild-type virus it is necessary to reduce the rate of susceptible individuals to the maximum extent. ${ }^{3}$ This may be achieved through adequate strategies, sufficient resources and the collaboration of governments and populations. It is also known that, once an extensive coverage is achieved, each step necessary to extend it calls for higher costs and efforts.

Susceptibility. In terms of vaccine-preventable diseases, there are different groups susceptible to having them. First of all, certain individuals cannot be vaccinated (because of their age or underlying disease, lack of access to health care, etc.) and there are others who, even though having been vaccinated, they are still susceptible (primary vaccine failure, lack of immune response, etc.). These individuals represent a health challenge because, on one hand, they are more vulnerable in case of an outbreak and, on the other hand, they favor virus circulation.

Secondly, aside this cohort of involuntarily or inevitably susceptible individuals, there is another group that could be defined as having an "elective vulnerability" (or inflicted vulnerability when it comes to minors). In this particular case, a choice is made, sometimes based on a professional indication and others on the grounds of beliefs, religion, ideology, etc. As a result, there is a group of people, whose number is reaching worrying proportions, who prioritize their choice above collective benefits of massive immunization. This has been facilitated by the strong promotion among certain social groups of the false statement that the risks of vaccination exceed those of susceptibility. The consequences of this decision are usually lessened temporarily by the massive population acceptance of vaccination, allowing to establish an epidemiological frontier based on "herd immunity."

Herd immunity. It is the protection of the population against an infection due to the presence of individuals who are immune to such infection. ${ }^{4}$ Such collective effect is proportional to the level of population immunization, either because they have had the disease or because they have been vaccinated. It has a beneficial effect by reducing the possibility of virus circulation and protecting susceptible individuals. Such effect is reduced when the proportion of non-immune individuals exceeds that of immune ones (Figure 1). This instrument, that allows to protect "involuntary" susceptible individuals, is at risk when used by a growing number of "elective" susceptible people since they have not been vaccinated..$^{5,6,7}$ An additional problem is that families who resist vaccination tend to group as per their beliefs or group belonging, therefore generating a "cluster" and increasing the risk of becoming vulnerable. ${ }^{8}$

\section{WHY NOT VACCINATE?}

a) Why not vaccinate my patients?: Physicians who recommend against vaccination

This is a highly complicated situation because it involves an in-depth discussion between physicians' free will in relation to their choices and the regulatory nature of immunization schedules. Any physician who, based on his / her knowledge construct, considers that vaccines may be more harmful than the disease they fight usually does so under an honest, although absolutely mistaken, belief. In fact, certain homeopathic tendencies hold this kind of stance. Discussing how much art and how much science involve our profession may lead us to making detrimental dialectical mistakes.

It is important to use public health to convey to the population and health care providers that the systematic use of vaccines is not the result of an hegemonic aspiration but of an in-depth analysis of its benefits and risks. In addition to the many academic and statistical endorsements, we should provide those who oppose vaccination an opportunity to be part of this discussion with scientifically accepted instruments. The systematic monitoring of adverse events, a thorough study of vaccines and their epidemiological surveillance should be transparent and accessible so that sound scientific evidence gains actual value against the myth of their futility.

In addition, we should not overlook that our responsibilities as physicians exceed individual medical actions to the extent that they may have an effect on the community. If we all prioritized our individual concerns over collective interests, public health would cease to exist and the consequences would be devastating. 
Lastly, we should also factor bioethical and medical-legal aspects into the equation. The legal frame of public immunization policies is designed to implement a proven technique of clinical effectiveness and efficacy that, even after weighing its risks, results in a robust solution to an actual health problem. The objective of these policies is to promote the common good over any objection. Therefore, when a government establishes its official immunization schedule, it acquires a regulatory nature (in Argentina, Act 22909 dated September $13^{\text {th }}$, 1983). ${ }^{9}$ Accordingly, recommendations of any board certified physician in the exercise of his/ her legal practice should not go against the law.

Now we should ask ourselves: Does recommending against vaccination involve malpractice? In principle it does not because there is no proven harm attributed to this decision. However, in case of an outbreak resulting in death or sequelae, non compliance with the law or the duties of a professional may certainly be demonstrated, together with the breach of applicable regulations and even negligence. This is where the judiciary, health authorities, scientific societies and universities should participate with clear messages.

\section{b) Why promote non vaccination?}

Many people or organizations propose and share information on the harmful effect of vaccines and the alleged advantages of not vaccinating. Among others, some have to do with religion, ideologies or conspiracy. These beliefs are as varying as they are inaccurate in their biological and epidemiological analysis. Their variety is the result of the accessibility to and proliferation of information in a poorly controlled media such as the Internet. Acting directly against these online forums would have no legal consequences and may even present us as censors of freedom of speech. However, when it comes to scientific publications, we should demand for methodological accuracy and responsibility, especially in relation to high impact health issues. What is more important is to analyze why these trends have such prestige among the population.

\section{c) Why refuse vaccination of my children?}

There are many reasons for this decision: religious beliefs, misinformation, lack of knowledge, fads or snobbism, extreme naturopathy, ideologies, etc. In a world where diversity and freedom of opinion are valued, it is logical that opinions are expressed across all walks of life.

We should also consider the false association between the publication of articles short of scientific rigor regarding thimerosal used in certain vaccines and autism. This information has been clearly and conclusively refuted by the scientific community but it has left an imprint

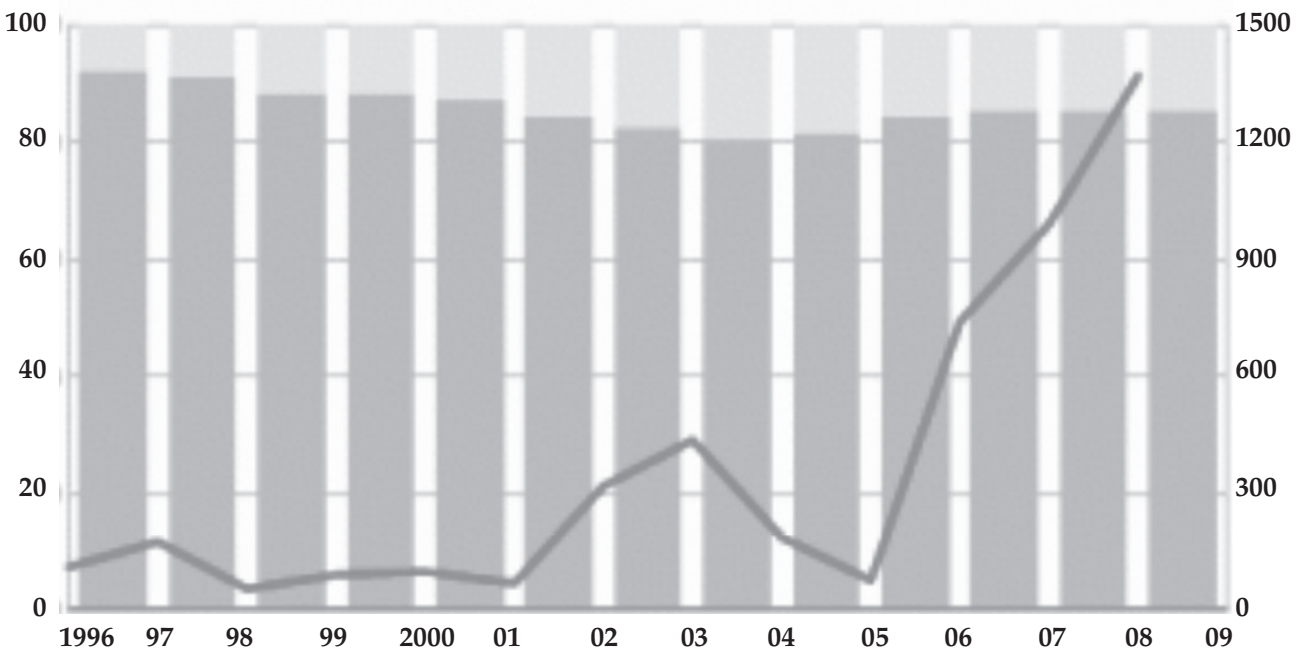


on the population, who not always has access to published corrections. ${ }^{10}$

In addition, we should mention a more current situation: certain increasingly broad sectors of the population are suspicious of the commercial interests of vaccine companies. The dissemination of advertisements, which is not always ethical, many times points to believing that problems are exaggerated in order to promote vaccine sales. It is worth considering whether this type of advertisements should be restricted or eliminated. Immunizations against high impact diseases should probably be a matter of State rather than a business decision.

Faced with the disturbing number of people who decide not to vaccinate their children, ignoring them would be a mistake. With no need to justify their reasons, the first step would be to understand why they choose a risk above other options and, therefore, try and improve our answers to their questions.

\section{CONSEQUENCES OF NON VACCINATION}

As a result of choosing not to vaccinate, we face many aspects that should not be overlooked. First of all, the possibility of having a child who may develop a disease or even die. Secondly, the perpetuation of transmission channels that increase the risks not only of that patient, but also of those "involuntary" susceptible individuals, who may even die for this reason. Thirdly, refusing to vaccinate allows an individual decision, if multiplied, to threaten the possibilities of eradicating a disease, which as mentioned before, has been one of the most transcendental achievements of preventive medicine. Lastly, it closes the door to the possibility of having their own children or grandchildren not vaccinated should these diseases be finally eradicated. And let us not forget costs in terms of lives lost, and the health and financial efforts made by communities when facing epidemics.

\section{Some matters for discussion:}

- Are parents free to decide not to have their children vaccinated?

- Are vaccines actually inconsistent with living a natural healthy life?

- Are we losing the dialectical battle?

\section{Proposals to face this problem}

- Educate and communicate. First of all, and in view of the lack of scientific evidence that demonstrates that vaccines pose a greater risk than what they prevent, we should understand that the challenge we face is a cultural one. So our first response to it should be education. We do not claim to have the only truth in this matter, but it is our obligation to provide a clear message regarding immunization policies, achievements and goals. We should demonstrate that the health of a community is a collective responsibility, and the population is not only a beneficiary, it also plays a leading role in the process. A serious debate with clear arguments is necessary in the physician's office and across the network of intermediate institutions and organizations involved in the health and educational process. A supportive and adequately informed society should accept that "if someone believes in the principles of vaccination, individual freedom to accept it should not be feared." ${ }^{\prime 1}$

- Epidemiological surveillance. We should prove to the scientific community and the general population that surveillance mechanisms, both of diseases and vaccinerelated adverse events, are important and effective tools, that do not respond to interests other than those of public health.

- The law at the service of health. The law is clear regarding the mandatory nature of children vaccination. The law should become the main instrument of governments to make community interests a priority over individual choices, especially when such choices lack scientific evidence. In addition, the judiciary's message should be clear and convincing, particularly in relation to those who advise against vaccination without giving a reason, and stating the responsibility of parents who refuse their children the right to vaccines in relation to the damage it may cause to them and their environment.

- State and rights. Vaccines are a right and an obligation. Compliance with the immunization schedule is a usual requirement to access education, social benefits, etc. Such requirements not only aim at warranting children vaccination, but also at ensuring that schools are capable of protecting susceptible individuals. This may lead to a contradictory situation where the victim of non vaccination is revictimized by the exclusion from such benefits, but parents should understand that this is the result of their decision and that it may be modified by accepting vaccination. 
Selective school eviction may even be proposed for non vaccinated children during situations of risk. ${ }^{12}$

- Policies and vaccines. If immunizations are considered a public interest tool, they should meet certain conditions in terms of research, production, marketing and advertisement. Disseminating information on diseases and their sequelae and promising a rescue effect for vaccines that are not affordable by most of the population on one hand result in a potential case of extortion and, on the other hand, a feeling of social discrimination between those who can afford vaccines and those who cannot. In addition, this situation undermines the level of trust the population has on immunizations.

- Informed consent. An official informed consent template may be established for legal tutors to sign when they refuse their children the right to vaccines, clearly explaining the risks to which they expose their children and the rest of the community. It should be noted that this implies the likelihood of assuming criminal and civil liabilities for the infection, sequelae or death of a child or the people in their setting that could become infected.

\section{CONCLUSIONS}

Today we approach this subject because vaccines are successful and make us regard the risk of any of these diseases as distant or uncommon. Should an Ebola epidemic occur, what would happen if there was a safe and effective Ebola vaccine as the measles vaccine? Would there be people more afraid of the vaccine than of the disease? Likewise, and compared to other treatments, would we refuse antibiotics in case of a bacterial sepsis because we are afraid of its adverse effects? This may be the basis for our everyday conversations with patients who are afraid of vaccines.

New and complex challenges lie ahead of us and we should face them as a "human village" rather than as individuals who coexist or compete. Once we eradicate measles, polio, etc., vaccinerelated adverse events will also disappear, as it occurred with the smallpox vaccine. Such legacy represents a moral obligation for our generation towards the next generation. Considering health as a collective construct with global impact is an ethical mandate that will make us stronger than if we were acting based on individual interests.

\section{Acknowledgments}

We would like to thank the staff of the Health and Community Action Center $\mathrm{N}^{\circ} 5$ of Ciudad Oculta, City of Buenos Aires, where people learn that health is built with effort and generosity, even in the most difficult situations.

\section{REFERENCES}

1. Organización Mundial de la Salud. Sarampión. Nota descriptiva $N^{\circ}$ 286. Ginebra, 2015. [Available at: http:// www.who.int/mediacentre/factsheets/fs286/es/]. [Accessed on: March 11, 2015].

2. Organización Mundial de la Salud. Poliomielitis. Nota descriptiva N $^{\circ}$ 114. Ginebra, 2014. [Available at: http:// www.who.int/mediacentre/factsheets/fs114/es/]. [Accessed on: March 16, 2015].

3. $63 .{ }^{a}$ Asamblea Mundial de la Salud. Erradicación mundial del sarampión: informe de la Secretaría. Ginebra: Organización Mundial de la Salud; 2010. [Available at: http:/ / apps.who.int/iris/bitstream/10665/4880/1/ A63_18-sp.pdf?ua=1]. [Accessed on: March 30, 2015].

4. Arrazola Martínez MP, de Juanes Pardo JR, García de CodesIlario A. Conceptos generales. Calendarios de Vacunación sistemática del niño y del adulto en España. Impacto de los programas de vacunación. Enferm Infecc Microbiol Clin 2015;33(1):58-65.

5. Vaqué Rafart J. Inmunidad de grupo. Significado e importancia. Revista clínica electrónica en atención Primaria. 2005;8. [Availableat:http:/ / www.fbjoseplaporte. $\mathrm{org} / \mathrm{rceap} /$ articulo2.php?idnum=8\&art=01]. [Accessed on: March 28, 2015].

6. Comin D. Vacunas: El riesgo de la pérdida de la inmunidad de grupo. Autismo diario. 2011. [Available at: http:// autismodiario.org/2011/10/05/vacunas-el-riesgo-dela-perdida-de-la-inmunidad-de-grupo/]. [Accessed on: March 30, 2015].

7. Arrazola Martínez MP, de Juanes Pardo JR. Inmunidad colectiva o de grupo. En: Asociación Española de Pediatría, ed. Manual de vacunas. $4^{\text {ta }}$ ed. Bilbao: AEP;2008:97-105. [Available at: http://vacunasaep.org/ manual/Cap3_6_Inmunidad_de_grupo.pdf]. [Accessed on: March 16, 2015].

8. Gostin LO. Law, ethics, and public health in the vaccination debates: politics of the measles outbreak. JAMA 2015;313(11):1099-100.

9. Ley 22909. Argentina. Ministerio de Salud de la Nación. Dirección Nacional de Control de Enfermedades Inmunoprevenibles. Buenos Aires, Argentina, 13 de septiembre de 1983. [Available at: http:/ / www.msal.gov. ar/dinacei/index.php/institucional/marco-legal/361ley-22909]. [Accessed on: March 30, 2015].

10. Artigas-Pallarés J. Autismo y vacunas: ¿punto final? Rev Neurol 2010;50(Supl 3):S91-9.

11. Sánchez-Ramón S, Fernández-Cruz E. Reflexión bioética sobre la inmunización de masas en Europa. Inmunología 2006;25(1): 67-71.

12. Yang YT, Silverman RD. Social distancing and the unvaccinated. N Engl J Med. 2015 Apr 16;372(16):1481-3. 